\title{
PERTAUTAN AGAMA DAN BUDAYA DALAM KEISLAMAN KOMUNITAS PITI JEPARA
}

\author{
Nur Kholis \\ nurkholis@unisnu.ac.id \\ Universitas Islam Nahdlatul Ulama Jepara
}

\begin{abstract}
This study aims to identify variants of Islamic religiosity in Chinese Muslim life as reflected in the organization of the Indonesian Chinese Islamic Association (Persatuan Islam Tionghoa Indonesia/PITI). This organization has distinctive features about how dialogue between Islam, Chinese ethnicity, implementation of Indonesian Islamic law legislation, and Javanese culture occured. This study uses a symbolic-interpretative anthropology approach. The conclusion of this study includes as the following (1) the organizational system of PITI in Jepara district is driven by indigenous Muslims who are active as administrators of the Nahdlatul Ulama in Jepara district and only two people of Chinese descents are administrators, while others are members; on the other hand, the involvement of "influential people" in the political world in Jepara also supports its existence. As for the organization funding is obtained and managed independently in the management level in Jepara; (2) Islamic characteristics of the PITI Muslim community in Jepara regency include muallaf status, feeling of being a minority but having sufficient economic, secular-materialist tendencies, prominent Chinese culture, and still strong pressure from family circles for Islam; and (3) the dimensions of Chinese socio-culture and the lives of indigenous people are more visible in socio-cultural life than the influence of religious norms.
\end{abstract}

Key words: religion and culture, Chinese Muslim, Indonesian Chinese Islamic Association, Jepara

\section{Pendahuluan}

Pertautan agama dan budaya merupakan suatu keniscayaan. Sejarah agama manapun membuktikan bahwa antara agama dan kehidupan manusia selalu terdapat ikatan yang kuat dan saling berkelindan. Hal ini mengingat agama hanya akan bisa mengada, bertahan dan lestari ketika dapat berinteraksi dengan dinamika kehidupan manusia. Demikian halnya dengan Islam sebagai agama dalam kehidupan manusia lintas bangsa, etnis, waktu, dan tempat. Peran manusia juga sangat penting dalam merealisasikan dan menjaga kelestarian ajarannya (Hidayat, 1996: 112; Soleh, 2003: 156). Gerak agama juga selalu berpusat dalam relasi gerak manusia, baik dengan Tuhan, dengan sesama manusia, ataupun manusia dengan alam (Azizy, 2000: 180; Sadra, 1981: 13-18; Fazlurrahman, 1989: 40). Dengan kata lain, agama selalu berdialektika dengan peradaban manusia, bukan semata-mata hanya untuk memuja Tuhan (Wahid, 1999; Abdalla, 2006; Muhammad, 2011). Memahami Islam yang universal juga perlu memahami manusia 
beserta pernak-pernik kehidupannya yang tercermin dalam bangunan budaya yang temporal dan sektoral.

Wacana tentang Islam lokal yang mengindikasikan interaksi antara Islam genuine dengan kebudayaan lokal tempat sekelompok Muslim melaksanakan agamanya menjadi bagian dari pergumulan tersebut. Diskursus semacam ini juga potensial untuk mengenali varian religiusitas manusia dalam perwujudan agamanya agar selalu relevan dengan konteks budaya yang beragam. Salah satu dari sekian varian religiusitas manusia adalah pengalaman dan pola keagamaan komunitas Muslim yang tergabung dalam Persatuan Islam Tionghoa Indonesia (PITI). Ia adalah organisasi yang menaungi kaum muslim keturunan Tionghoa yang ada di Indonesia agar dapat saling berkomunikasi dan sebagai jalur berdakwah di kalangan etnis Tionghoa. Organisasi ini didirikan pada 14 April 1961 di Jakarta untuk menjadi "rumah singgah" bagi sesama etnis Tionghoa mengingat keberadaan Muslim ini merasa tidak diterima di kalangan masyarakat etnis mereka sendiri yang rata-rata penganut Kristen, Budha dan Konfusianisme, sementara di sisi lain masyarakat pribumi Indonesia juga belum menerimanya secara penuh.

Situasi dan kondisi yang sedemikian membuat komunitas ini memiliki pengalaman keagamaan tersendiri. Pandangan hidup dengan nilai-nilai yang dibangunnya dalam rangka mengikuti ajaran Islam kemudian menjadikannya membangun pola keagamaan yang khas. Kekhasan ini tentu saja didukung dan dikuatkan oleh perasaan bersuku-bangsa dalam bingkai nilai-nilai hidup Tionghoa, sedangkan mereka juga tidak dapat melepaskan ketundukannya di bawah kedaulatan hukum Indonesia serta kungkungan budaya lokal di mana mereka tinggal. Dengan demikian, melekatnya Islam dalam kehidupan mereka juga berpotensi bersinggungan dengan dinamika politik-ekonomi dan budaya di Indonesia.

Salah satu dari bentuk dinamika yang pernah terjadi secara nasional adalah diubahnya singkatan PITI pada tahun 1972 menjadi "Persatuan Iman Tauhid Indonesia" sebagai jalan "penyelamatan diri" dari tekanan politik pemerintah yang sedang berkuasa. Pada saat itu, instruksi dari pemerintah (tertanggal 14 Desember 1972) menekankan agar organisasi ini tidak berciri etnis tertentu. Kemudian PITI kembali menjadi "Persatuan Islam Tionghoa Indonesia" yang ditetapkan dalam rapat pimpinan organisasi pada pertengahan Mei 2000. Di samping itu, peristiwa demi peristiwa yang menandakan sikap anti keturunan Tionghoa juga kerapkali terjadi di berbagai kota di Indonesia. Sejarah mencatat pelbagai kerusuhan seperti kerusuhan anti Tionghoa tahun 1918 di Kudus, tahun 1963 di Bandung, Sukabumi dan beberapa kota di Jawa Tengah, tahun 1968 di Surabaya, tahun 1973 di Bandung, tahun 1974 di Jakarta, tahun 1981 di Semarang, tahun 1997 di Pekalongan, Ujung Pandang, Banyuwangi, hingga sepanjang bulan Mei 1998 di berbagai daerah di Indonesia seperti Medan, Padang, Samarinda, Jakarta, Solo, Lampung dan Tanjung Balai. Kerusuhan-kerusuhan tersebut menekan keberadaan etnis Tionghoa secara menyeluruh, termasuk dalam hal kehidupan keagamaannya. 
Komunitas etnis Tionghoa juga mengalami keterombang-ambingan sistemik. Misalnya, pemerintah Orde Baru melarang warga Tionghoa menampakkan ekspresi kebudayaan dan religiusitasnya di hadapan khalayak publik melalui Instruksi Presiden (Inpres) Nomor 14 Tahun 1967. Kebijakan ini kemudian dihapus oleh Presiden Abdurrahman Wahid dengan mengeluarkan Peraturan Pemerintah Nomor 6 Tahun 2000 dan Keputusan Presiden (Keppres) Nomor 19 Tahun 2001 tertanggal 9 April 2001 yang meresmikan Imlek sebagai hari libur fakultatif. Setelah itu, pada era kepemimpinan Presiden Megawati Soekarnoputri, mulai tahun 2003 Imlek secara resmi dinyatakan sebagai hari libur nasional.

Dengan demikian, bagaimana dengan kehidupan keislaman warga Tionghoa yang tergabung dalam organisasi PITI di Kabupaten Jepara? Komunitas PITI Kabupaten Jepara adalah bagian sektoral dari keberadaan etnis Tionghoa yang beragama Islam di Indonesia. Ia tidak terlepas dari dampak politik-ekonomi nasional, keterikatan etnis Tionghoa berikut budayanya, serta kebiasaan hidup masyarakat pribumi Jawa di Jepara. Untuk itulah, tulisan ini hendak menelusuri lipatanlipatan keagamaan Muslim Tionghoa di Jepara dalam ruang besar perjumpaan Islam dengan budaya Cina di mana Nabi Muhammad S. A. W. - tokoh paling utama dalam agama Islam - telah mengakuinya sebagaimana dalam Hadits. Pembacaan dampak dari rentetan peristiwa yang menyangkut hak hidup komunitas Tionghoa juga tidak bisa ditinggalkan begitu saja ketika hendak memahami bagaimana mereka beragama. Selain itu, secara lebih khusus, pola organisasi PITI Kabupaten Jepara juga perlu dikaitkan dengan tata kehidupan masyarakat Jawa di Jepara.

Terdapat beberapa pertimbangan mengapa studi ini menjadi penting dilakukan, di antaranya (1) warga Tionghoa di Jepara berperan signifikan dalam dinamika hidup masyarakat Jepara, (2) komunitas Muslim Tionghoa yang tergabung dalam organisasi PITI Kabupaten Jepara perlu diperhatikan sebagai bagian dari fenomena keagamaan Islam di Indonesia, (3) terkait dengan kebutuhan akademik, khususnya bagi peneliti, praktik keagamaan komunitas PITI Jepara perlu dicermati dari perspektif hukum Islam, baik dalam koridor fiqh maupun hukum Islam Indonesia, (4) varian religiusitas komunitas Tionghoa di Jepara perlu diketahui bukan hanya oleh masyarakat Jepara, tetapi juga oleh semua lapisan masyarakat sebagai khasanah peradaban manusia.

Atas dasar pertimbangan di atas, studi ini berupaya untuk menemukan (1) pemahaman terhadap sistem keorganisasian PITI Kabupaten Jepara; (2) karakteristik keislaman komunitas Muslim di dalamnya; dan (3) pola interaksi antara Islam dengan kehidupan sosial-budaya komunitas Muslim PITI Kabupaten Jepara dan masyarakat pribumi Jepara.

\section{Perjumpaan Agama dan Budaya Lokal di Indonesia}

Kajian mengenai pergumulan Islam dengan budaya lokal telah mengada dan berkelindan sekian lama mewarnai studi Islam dan masyarakat di Indonesia. Dari laju keilmuan tersebut tentu terdapat banyak literatur mengenai persoalan "tawar menawar" antara 
keduanya, Islam dan budaya lokal, terjadi dan terdokumentasikan. Studi antropologi agama tentang keislaman komunitas PITI kabupaten Jepara disadari akibat perjumpaan intelektual penulis dengan beberapa kejadian dan pustaka mengenai keagamaan "komunitas khusus" dalam Islam. Beberapa pustaka yang mengilhami penulis untuk mengembangkan pencermatan atas praktik keagamaan komunitas khusus tersebut di antaranya adalah karya Clifford Geertz (1960), Erni Budiwanti (2000), Nur Syam (2005), Arifuddin Ismail (2012), dan Munawir Aziz (2014). Karya-karya ini dapat dijelaskan secara singkat sebagai berikut.

Pertama, karya Clifford Geertz yang berjudul The Religion of Java (1960), yang banyak dikutip para peneliti karena dianggap berhasil meretas persinggungan agama dan budaya, di samping kemunculannya pada masa belum banyaknya referensi tentang antropologi, khususnya di Indonesia. Penelitian yang dilakukan Geertz di wilayah Mojokerto (Pare), Jawa Timur, ini menyibak persinggungan unsur Jawa dan Islam dalam kehidupan masyarakat Jawa. Geertz menegaskan bahwa agama tradisional memiliki stereotipe yang kaku dan penuh kesimpangsiuran antara mitos dan magis, sedangkan agama dunia lebih abstrak, secara logika lebih koheren, dan lebih terungkap secara umum. Dengan pemilahan tersebut, Geertz menyimpulkan agama di Jawa (termasuk Islam) tersusun dengan proses asimilasi dan bercorak sinkretis. Hampir semua unsur dalam agama dan budaya melebur menjadi satu dan sulit dipisahkan, meskipun sebelumnya dihadapkan pada pilihan konflik ataukah integrasi.
Menurutnya, Islam di Jawa adalah agama Jawa (The Javanese Religion) itu sendiri.

Kedua, karya monumental dari Erni Budiwanti yang berjudul Islam Sasak; Wetu Telu versus Waktu Lima (2000). Karya ini diterbitkan dalam bentuk buku dari disertasi Budiwanti berjudul Religion of the Sasak; An Etnographic Study of the Impact of Islamisation on the Wetu Telu of Lombok di Monash University, Australia, pada tahun 1997. Budiwanti melaksanakan penelitiannya dengan metode participation observation (pengamatan terlibat) dalam dua tahapan (Oktober 1992 - Januari 1993, dan Januari 1994 - Januari 1995) dengan memusatkan perhatian pada masalah konflik ideologis antara dua kelompok kultural religius pada masyarakat Sasak Bayan di Lombok, yaitu Wetu Telu dan Waktu Lima. "Islam Sasak" sendiri pada dasarnya juga Islam, sebagaimana Islam Jawa, Islam Melayu, dan sebagainya. Islam Sasak "asli" bernama Wetu Telu, jenis Islam lokal yang berpadu dengan nilai-nilai adat. Agama ini sering dipertentangkan dengan Waktu Lima, jenis Islam puritan yang ada di Lombok. Buku ini menunjukkan adanya "serangan" dakwah terus-menerus yang dilakukan Islam Waktu Lima terhadap Wetu Telu. Dari penelitian atas persoalan tersebut, Erni Budiwanti menegaskan bahwa pemilahan dua kelompok di atas tidak sepenuhnya merepresentasikan atau mengkonfirmasikan dikotomi santri-abangan versi Clifford Geertz, meskipun dalam batas-batas tertentu Wetu Telu memiliki kemiripan dengan ciri kaum abangan, dan Waktu Lima pun memiliki kategorisasi yang relatif sama dengan kaum santri. Pembedaan antara keduanya harus dilihat dengan pertolongan 
sebuah model dinamik yang menjadi variabel-variabel perubahan dan intensitas konflik ideologis, bukan dengan cara yang dikotomis dan statis (Budiwanti, 2000: 342).

Ketiga, karya Nur Syam yang berjudul Islam Pesisir (2005). Wilayah Tuban yang menjadi medan penelitian ini digambarkan dengan model keagamaan Muslim di Jawa yang selalu mengalami asimilasi dengan budaya lokal yang telah dibangun Hinduisme. Karya Syam yang mengkaji Islam pesisir melalui tinjauan teori konstruksi sosial ini menggambarkan bahwa Islam pesisir yang sering ditipologikan sebagai Islam murni, karena bersentuhan pertama kali dengan tradisi besar Islam, ternyata adalah Islam yang kolaboratif, yaitu corak hubungan antara Islam dengan budaya lokal yang bercorak inkulturatif sebagai hasil konstruksi bersama antara agen (elitelit lokal) dengan masyarakat dalam sebuah proses dialektika yang terjadi secara terus menerus. Ciri-ciri Islam kolaboratif adalah bangunan Islam yang bercorak khas, mengadopsi unsur lokal yang tidak bertentangan dengan Islam dan menguatkan ajaran Islam melalui proses transformasi secara terus menerus dengan melegitimasinya berdasarkan atas teks-teks Islam yang dipahami atas dasar interpretasi elit-elit lokal. Menurut Syam, Islam yang bernuansa lokalitas tersebut hadir melalui tafsiran agen-agen sosial yang secara aktif berkolaborasi dengan masyarakat luas dalam kerangka mewujudkan Islam yang bercorak khas, yaitu Islam yang begitu menghargai terhadap tradisi-tradisi yang dianggapnya absah seperti ziarah kubur suci, menghormati terhadap masjid suci dan sumur-sumur suci. Medan budaya tersebut, sebagaimana dapat ditemukannya di Tuban, dikaitkan dengan kreasi para wali atau penyebar Islam awal di Jawa. Motif untuk melakukan tindakan tersebut adalah untuk memperoleh berkah. Melalui bagan konseptual "in order to motive" atau "untuk memperoleh berkah," ternyata juga penting dilihat dari bagan konseptual "because motive" atau orang pergi ke tempat keramat adalah "disebabkan" oleh keyakinan bahwa medan-medan budaya tersebut mengandung sakralitas, mistis dan magis. Namun demikian, keduanya tidak cukup untuk menganalisis tindakan itu, maka diperlukan bagan konseptual "pragmatic motive" yaitu orang pergi ke medan budaya disebabkan oleh adanya motif pragmatis atau kepentingan yang mendasar di dalam kehidupannya.

Keempat, karya Arifuddin Ismail yang diterbitkan oleh Pustaka Pelajar dengan judul Agama Nelayan; Pergumulan Islam dengan Budaya Lokal (2012) dari disertasinya pada Program Doktoral by research di Universitas Islam Negeri Sunan Kalijaga, Yogyakarta pada tahun 2012. Disusunnya buku ini berangkat dari keinginan Ismail untuk mengungkap salah satu aspek dari religiusitas nelayan, yakni menyangkut ritual nelayan. Studi ini dilakukan di desa Pambusuang, kecamatan Balanpia, kabupaten Poliwali-Mandar, propinsi Sulawesi Barat. Setelah mengamati praktik ritual nelayan Pambusuang, Ismail memahami bahwa pelaksanaan ritual sejatinya bukan sekadar bagian dari "kewajiban" yang harus dilakukan, tetapi sekaligus "transaksi spiritual" antara manusia dengan Tuhan. Oleh karena itu, motivasi ritual nelayan dipahaminya terdiri 
dari dua tingkatan, yakni (1) sebagai motif peneguhan hati dan keselamatan, (2) sebagai motif peningkatan pendapatan (Ismail, 2012: 167). Selain itu, Ismail juga "menemukan" dominasi sufistik dalam praktik ritual nelayan Pambusuang. Mappatama' koroang (khataman al-Qur'an), maulid Nabi, peca sure' dalam bulan Muharam, makkuliwa, maqappu, akkeka, massunnang, likkaq, dan takziah merupakan media persemaian Islam lokal di Pambusuang-Mandar. Artinya, ritual bukan sekadar dimaknai oleh nelayan Pambusuang sebagai semata-mata rentetan upacara, namun ditempatkan sebagai daya dorong dalam membentuk perilaku keseharian yang luhur, baik terhadap Tuhan, sesama manusia, maupun alam.

Kelima, karya Munawir Aziz dengan judul Lasem, Kota Tiongkok Kecil: Interaksi Tionghoa, Arab, dan Jawa dalam Persilangan Budaya Pesisiran, yang diterbitkan oleh Penerbit Ombak (2014). Karya ini menguak persinggungan budaya antar etnis di Indonesia di wilayah kecamatan Lasem, Kabupaten Rembang, Jawa Tengah. Unsur budaya yang mereka bawa dari lingkaran kebangsaan nenek moyangnya mampu menjadikan mereka memiliki nilai hidup, bahasa, seni, mitos, magi dan tradisi yang berbeda. Tidak jarang ditemukan potensi konflik antar mereka, meskipun pada tataran kehidupan praktis hanya menampak pada momen-momen tertentu. Karya ini bermula dari tesis Aziz ketika menyelesaikan pendidikan pascasarjana di Center for Religius and Cross-Cultural Studies (CRCS) di Universitas Gadjah Mada tentang pencermatannya atas interaksi ketiga etnis Tionghoa, Arab, dan Jawa beserta situs-situs budayanya di Lasem. Bukan konfliknya yang menjadi perhatian Aziz dalam tulisan ini, tetapi keharmonisan antar etnis itulah yang dikaji dengan pendekatan harmoni. Pendekatan ini dipilih karena relasi warga Tionghoa, santri, dan pribumi didasarkan pada kesadaran dan usaha bersama untuk menjaga harmoni dengan tetap mengakui perbedaan kultur dan kepercayaan masingmasing.

Dari rentetan pustaka yang penulis tinjau di atas, tidak ditemukan kajian dan penjelasan mengenai keislaman komunitas Muslim PITI Kabupaten Jepara. Itu sebabnya, studi ini sekiranya dapat dijadikan dedikasi baru ke arah pengayaan khasanah keilmuan Islam, khususnya penggunaan antropologi dalam kaitannya sebagai pengembangan studi Islam di Indonesia.

\section{Persatuan Islam Tionghoa Indonesia (PITI) Kabupaten Jepara}

\section{1. Sistem Keorganisasian PITI} Kabupaten Jepara

PITI Kabupaten Jepara merupakan organisasi tingkat daerah yang wilayah kinerjanya -jika dianalogikan dengan struktur kepemerintahan - berada setingkat dengan pemerintah Kabupaten. Ia merupakan organisasi yang melaksanakan visi dan misi organisasi PITI tingkat nasional yang berada dalam naungan koordinasi PITI wilayah Jawa Tengah. Secara struktural, kepengurusan PITI terklasifikasi dalam tingkat Nasional (Dewan Pengurus Pusat), tingkat Propinsi (Dewan Pengurus Wilayah), dan tingkat Kabupaten (Dewan Pengurus Daerah).

PITI Kabupaten Jepara berdiri pada tahun 2005, meskipun PITI secara nasional 
telah berdiri tahun 1961. Sebagaimana lazimnya sebuah organisasi, PITI dipimpin oleh seorang ketua yang dibantu sekretaris dan bendahara, serta dilengkapi dengan devisi-devisi yang menjalankan tugas keorganisasiannya secara lebih spesifik. Di samping itu, dalam rangka "penguatan," keorganisasian PITI Kabupaten Jepara juga dinaungi oleh dewan penasehat dan pembimbing yang pada saat tertentu juga berperan sebagai penyantun. Meskipun PITI Kabupaten Jepara merupakan organisasi Persatuan Islam Tionghoa Indonesia yang ada di Jepara, yang secara jelas-jelas disebut kalimat Tionghoa, akan tetapi tidak semua pengurus dan anggota merupakan warga keturunan Tionghoa yang berstatus sebagai warga Negara Indonesia (WNI). Bahkan, secara personalia, hanya dua orang saja pengurus PITI Kabupaten Jepara yang "asli" keturunan Tionghoa, sementara pengurus lainnya adalah warga yang beretnis Jawa. Warga keturunan etnis Tionghoa lainnya yang tergabung di dalamnya "hanya" sebagai anggota. Keberadaan pengurus yang beretnis Jawa ini sekaligus menunjukkan bahwa PITI Kabupaten Jepara juga bermula dari inisiasi sekelompok Muslim Jawa yang tergabung dalam organisasi Nahdlatul Ulama' Jepara. Namun demikian, perbandingan proporsi ini tidak selalu terjadi di PITI daerah lain.

Alasan utama yang menjadi dasar pendirian PITI Kabupaten Jepara adalah semangat berdakwah Islam, khususnya dalam hal pendampingan keislaman bagi para muallaf, terutama warga Tionghoa. Misi pengislaman ini sebagaimana terlihat dari pernyataan ketua PITI Kabupaten Jepara, Nur Soleh sebagai berikut.
"Awalnya, dulu saya sebagai pengurus PITI Kabupaten Kudus. Terus, sesudahnya saya berdomisili di Jepara, saya ingin melanjutkan misi yang dulu pernah saya lakukan. Misinya dakwah. Ya,... mengislamkan orang itu kan bagian dari dakwah. Kemudian saya ajak teman-teman, termasuk pak Hamzah itu, untuk mendirikan PITI."

Sejalan dengan pernyataan ketua PITI Kabupaten Jepara, sekretaris PITI Kabupaten Jepara, Hamzah, juga mengungkapkan seperti ini.

"Maksud kita itu memang dakwah. Dulu itu pak Soleh sering mengikuti pak kyai Sayuti (sesepuh PITI Jawa Tengah) yang sering mengislamkan orang. Terus beliau pak Soleh itu, setelah sudah tinggal di Jepara, mengajak saya dan pak Ngadiman. Jika ada yang dapat hidayah dari Allah, ya kita openi (memperhatikan dengan tindakan nyata). Orang yang masuk Islam, terus jadi muallaf, itu kita tampung. Karena mereka butuh tempat yang menaungi. Ya, PITI ini tempat bernaung bagi muallaf terutama Tionghoa. Memang PITI ini organisasi minoritas dari kelompok minoritas. Warga Tionghoa di Indonesia, termasuk di Jepara, ini kan mionoritas."

Hingga saat ini, PITI Kabupaten Jepara telah mengalami beberapa perode kepengurusan terhitung sejak 2005. Kepengurusan tahun ini mengalami kemunduran dan keterlambatan. Sebagaimana diakui oleh pengurusnya sendiri, sepanjang perannya di Jepara, kepengurusan periode pertama relatif lebih aktif dibanding periode-periode sesudahnya. Hal tersebut disebabkan karena waktu yang dimiliki oleh pengurusnya tersita oleh 
urusan kegiatan lain sesuai profesi masingmasing pengurus. Selain itu, pengurus PITI Kabupaten Jepara banyak yang merangkap jabatan di organisasi lain, seperti terlibat dalam kepengurusan NU maupun organisasi sosial-masyarakat lainnya. Menurunnya pendapatan bisnis dari sebagian pengurus juga turut memengaruhi tingkat kualitas dan kuantitas kegiatan organisasi ini. Bahkan, pergeseran iklim politik di Jepara disadari oleh pengurusnya sebagai faktor yang signifikan.

Penurunan tingkat keaktifan organisasi tampak jelas dari menurunnya kegiatan PITI Kabupaten Jepara terhitung sejak tahun 2014. Pada tahun-tahun berikutnya juga tidak ada program yang bersifat "go public" seperti pada tahuntahun periode pertama. Program pengadaan dan pembagian kurban pada hari raya Idul Adha, misalnya, yang dulunya setiap tahun diadakan di berbagai kecamatan yang dituju, pada tahun-tahun belakangan tidak berhasil diadakan. Bahkan, konsolidasi antara pengurus dan anggota hanya berlangsung antar individu dan bersifat personal, meskipun tentu saja tidak meninggalkan nuansa bimbingan agama. Gambaran keadaan ini sebagaimana ungkapan sekretaris PITI Jepara di bawah ini.

"Salah satu ikon muallaf PITI itu bernama Muhammad Sulton. Dia warga Selandia Baru yang menikahi orang Jepara. Alhamdulillah, karena suatu hidayah dia masuk Islam. Ya, yang mengislamkan itu ya pak Nur Soleh itu. Nah, itu setiap lebaran ke rumah pak Soleh. Bisa dipastikan seperti itu. Untuk dibimbing lah."

3. 2. Karakteristik Keislaman Komunitas Muslim PITI Kabupaten Jepara
Sebagai organisasi minoritas dari kelompok minoritas di Indonesia, komunitas Muslim PITI Kabupaten Jepara memiliki karakteristik tertentu, yang dalam tulisan ini disampaikan secara garis besarnya.

\section{(1). Kemuallafan}

Pertama, karakteristik kemuallafan Muslim PITI Kabupaten Jepara. Pada kenyataannya, PITI kabupaten Jepara merupakan wadah bagi muallaf yang bukan hanya warga etnis Tionghoa saja, melainkan juga terdapat etnis Jawa dan warga negara asing yang berdomisili di Indonesia. Mengingat mereka belum lama memeluk agama Islam, ditambah latar belakang mereka yang tidak mendukung keislamannya, baik dari faktor keluarga, situasi dan kondisi kehidupan yang jauh dari wacana keislaman, maka mereka belum memiliki perhatian yang cukup untuk mempraktikkan ajaran Islam. Hal ini seperti tampak pada masih rendahnya kemampuan mereka dalam mengamalkan salat, puasa, zakat, dan haji. Dalam keadaan seperti ini mereka sangat membutuhkan bimbingan dan pendampingan.

\section{(2). Sebagai Minoritas Sosial dan} Kemampuan Ekonomi

Kedua, perasaan sebagai minoritas sosial di Jepara namun disertai kemampuan ekonomi yang kuat menjadi pendorong munculnya karakteristik tertentu pada sebagian anggota PITI. Hal ini tampak dalam beberapa kegiatan yang mereka selenggarakan, baik terkait tempat, alat transportasi, alat komunikasi, hidangan, maupun fasilitas lainnya yang menampakkan kelas sosial tertentu yang mapan.

(3). Sekularis-Materialis 
Ketiga, kecenderungan sekularismaterialis dalam bersikap. Dalam beberapa hal, mereka beranggapan tidak adanya keterkaitan antara kehidupan agama dan kehidupan duniawi. Seolah-olah agama hanya untuk ruang ritus, mitis, dan mistik belaka, sementara persoalan hidup cukup diselesaikan dengan hukum alam yang kapitalis-materialis-individualis.

\section{(4). Seni-Budaya Tionghoa}

Keempat, penonjolan seni-budaya Tionghoa menjadi karakteristik Muslim Tionghoa yang tidak dimiliki oleh Muslim pribumi Jepara; misalnya dalam hal retorika, berpakaian, bangunan rumah ibadah, memiliki nama ganda (Indonesia dan Tionghoa) sebagai identitas, warna dan simbol kesukuan, dan kuliner.

\section{(5). Tekanan Keluarga}

Kelima, adanya tekanan dari lingkungan keluarga akibat keislaman yang dipilihnya. Tekanan ini tidak hanya sebatas mengenai terhapusnya pengakuan keturunan dari keluarga, akses ekonomi dan sosial dalam relasi sesama etnis, namun hingga menyangkut persoalan tata cara pemakaman ketika Muslim Tionghoa yang bersangkutan meninggal. Salah satunya terbukti dari adanya konflik keluarga terkait pemakaman tersebut yang pada akhirnya harus dimakamkan dengan cara-cara yang disetujui oleh anggota keluarga tertua yang kebanyakan nonmuslim. Sebagai akibatnya, disinyalir adanya beberapa Muslim Tionghoa di Jepara yang tidak masuk organisasi PITI karena alasan penyamaran identitas dan status keislamannya.

Selain itu, mengenai pola interaksi antara Islam, kehidupan sosial-budaya Muslim PITI Jepara dan masyarakat pribumi
Jepara masih dapat diamati dengan aneka dialektikanya. Hanya saja, interaksi antara ketiga hal tersebut hanya terjadi pada kesempatan-kesempatan tertentu. Dengan kata lain, dalam interaksi antara ketiga hal tersebut yang paling tampak dalam pengamatan adalah faktor kehidupan sosialbudayanya, sementara faktor norma agama tidak begitu tampak. Demikian pula, dan pada saat bersamaan, pola interaksi antara Islam, kehidupan sosial-budaya antar anggota komunitas PITI Jepara, dan masyarakat pribumi, sejauh ini masih terkesan adanya ketegangan dalam persoalan pemahaman antara agama dan etnisitasnya yang rata-rata nonmuslim. Pada tahap tertentu, dirasa perlu penelusuran lebih lanjut mengenai interaksi tersebut sampai pada level personal.

\section{Simpulan}

Setelah melakukan paparan dan kajian, dari studi ini dapat disimpulkan dalam beberapa poin penting. Pertama, sistem keorganisasian PITI Kabupaten Jepara digerakkan oleh Muslim pribumi yang aktif sebagai pengurus Nahdlatul Ulama' di Kabupaten Jepara. Hanya dua orang saja warga keturunan Tionghoa yang menjadi pengurus, sementara lainnya sebagai anggota. Di sisi lain, keterlibatan "orang berpengaruh" dalam dunia perpolitikan di Jepara juga turut mendukung eksistensinya. Adapun mengenai pendanaan organisasi didapat dan dikelola secara swadaya dalam level kepengurusan di Jepara. Kedua, karakteristik keislaman komunitas Muslim PITI Kabupaten Jepara di antaranya adalah status muallaf, perasaan sebagai minoritas namun berkecukupan ekonomi, kecenderungan sekularis- 
materialis, penonjolan seni-budaya Tionghoa, dan masih kuatnya tekanan dari lingkaran keluarga. Ketiga, dalam interaksi antara Islam "genuine," dimensi sosialbudaya Tionghoa, dan kehidupan masyarakat pribumi lebih menampak dalam kehidupan sosial-budaya dibanding pengaruh norma agama.

\section{Daftar Pustaka}

Abdalla, Ulil Abshar. 2006. Menjadi Muslim Liberal. Jakarta: JIL, Freedom Institute, Penerbit Nalar.

Budiwanti, Erni. 2000. Islam Sasak; Wetu Telu versus Waktu Lima. Yogyakarta: LKiS.

Aziz, Munawir. 2014. Lasem, Kota Tiongkok Kecil: Interaksi Tionghoa, Arab, dan Jawa dalam Persilangan Budaya Pesisiran. Yogyakarta: Ombak.

Azizy, Ahmad Qodri A.. 2000. Islam dan Permasalahan Sosial: Mencari Jalan Keluar. Yogyakarta: LKiS.

Danim, Sudarwan. 2002. Menjadi Peneliti Kualitatif. Bandung: Pustaka Setia.

Fazlurrahman. 1989. Islam. terj. Ahsin Mohammad. Bandung: Penerbit Pustaka.

Geertz, Clifford. 1960. The Religion of Java. Chicago: The University of Chicago Press.

Hidayat, Komaruddin. 1996. Memahami Bahasa Agama; Sebuah Kajian Hermeneutik. Jakarta: Penerbit Paramadina.

Ismail, Arifuddin. 2012. Agama Nelayan; Pergumulan Islam dengan Budaya Lokal. Yogyakarta: Pustaka Pelajar. Miles, M.B. \& A.M. Huberman. 1994. Qualitative Data Analysis; A
Sourcebook of New Methods. Thousand Oaks, CA: Sage.

Muhammad, Husein. 2011. Mengaji Pluralisme kepada Mahaguru Pencerahan. Bandung: Mizan.

Pawito. 2007. Penelitian Komunikasi Kualitatif. Yogyakarta: LKiS.

Sadra, Mulla. 1981. al-Asfar alArba'ah fi al-Hikmah al-Muta'aliyah. Jilid I. Beirut: Dar al-Ihya al-Turats al-Arabi.

Soleh, A. Khudori. 2003. Pemikiran Islam Kontemporer. Yogyakarta: Jendela.

Syam, Nur. 2005. Islam Pesisir. Yogyakarta: LKiS. 2011. Madzhab-madzhab Antropologi. Yogyakarta: LKiS.

Wahid, Abdurrahman. 1999. Tuhan Tidak Perlu Dibela. Yogyakarta: LKiS. 